\title{
Annual variation of estuarine and oceanic oyster Crassostrea virginica Gmelin hemocyte capacity
}

\author{
William S. Fisher, Marnita M. Chintala and Mark A. Moline \\ Center for Environmental and Estuarine Studies. University of Maryland. Hom Point Environmental \\ Laboratories, Cambridge, Maryland, U.S.A.
}

\begin{abstract}
Defense-related hemocyte activities of American oysters Crassostrea virginica Gmelin from an oceanic and an estuarine habitat were monitored from spring to winter of 1987 at a constant temperature $\left(15^{\circ} \mathrm{C}\right)$. The ability of cells to spread to an ameboid shape in vitro at ambient salinity and after an acute change in salinity was much reduced from late spring to early fall. This summer-stress period was also indicated by laboratory experiments. Stress may have been due to high water temperatures but spawning efforts may have also contributed. Reduced hemocyte activity occurred at a time when infections by two major oyster parasites are at a peak in enzootic areas. Hemocyte locomotion rates fluctuated during the study period but did not show a significant cyclic pattern. At all times of the year, hemocytes responded to acute in vitro changes in salinity according to a pattern previously described. Oysters inhabit a wide range of salinities and temperatures and these data indicate that natural environmental fluctuations may influence their defensive capacity.
\end{abstract}

Key words: Environmental physiology; Invertebrate defense mechanism; Invertebrate immunology; Invertebrate leucocyte

\section{INTRODUCTION}

Environmental factors can play a major role in the ecology of eastern oysters, also called American oysters Crassostrea virginica Gmelin, which inhabit oceanic and estuarine waters in North America along the coasts of the Atlantic Ocean and Gulf of Mexico. Within this range, and often within a single habitat, oysters are exposed to wide variations of salinity and temperature. These two factors are very important in North American oyster fisheries because two major diseases of $C$. virginica, caused by the protozoans Haplosporidium nelsoni Haskin et al. and Perkinsus marinus Levine, reach epizootic proportions in high-salinity warm-water conditions (Hewatt \& Andrews, 1956; Haskin \& Ford, 1982; Andrews, 1984). Low-salinity intolerance by $H$. nelsoni parasites undoubtedly contributes to this epizootiology (Ford \& Haskin, 1988) but does not appear to be a factor with $P$. marinus which can sporulate and survive in salinities 
as low as $6 \%$ in vitro (Chu \& Greene, in press). Host defense mechanisms are also influenced by the environment (Fisher, 1988) and may play a role in oyster disease susceptibility.

Hemocytes of marine bivalve molluscs are believed to play a primary role in internal defense (Feng et al., 1977; Cheng, 1981), responsible for wound plugging and phagocytosis or encapsulation of invading microorganisms. These hemocyte functions are susceptible to environmental factors, especially temperature (J.S. Feng, 1966; S. Y. Feng, 1966; Acton \& Evans, 1968; Feng \& Feng, 1974; Foley \& Cheng, 1975). To effect their defense-related functions, the hemocytes must be capable of several underlying activities, such as aggregation, spreading, nonself recognition, and locomotion (Fisher, 1986),

Recent studies have shown that acute and short-term changes in salinity and temperature can affect cell spreading, locomotion (Fisher \& Newell, 1986a; Fisher \& Tamplin, 1988), and foreign-particle binding (Fisher et al., 1987; Fisher, 1988a). Standardized assays conducted in wet and dry years (Fisher \& Newell, 1986a; Fisher \& Tamplin, 1988) showed high year-to-year variation in defense-related hemocyte activities. The monitoring study described here was conducted to determine whether annual fluctuations in the environment also influenced the physiology of the hemocytes and their defense-related activities.

\section{Materials AND Methods}

\section{MONITORING ESTUARINE AND OCEANIC HABITATS}

Oysters were collected from areas that were considered nonenzootic for the two major oyster diseases, P. marinus and H. nelsoni. Estuarine oysters were dredged monthly (March-December 1987) from Double Mills on the Tred Avon River (TA), a tributary of the Choptank River. Salinity at the TA site is normally too low for either $H$. nelsoni or $P$. marinus to occur with high incidence or severity. Oceanic oysters were collected monthly (March-October 1987) at low tide from Burton's Bay, Wachapreague (WP), Virginia. Although the WP oysters have been exposed to both diseases, $P$. marinus is rarely found and $H$. nelsoni has never caused serious mortalities (E. Burreson, Virginia Institute of Marine Science, pers. comm.). Salinities at both sites remained relatively constant throughout the sampling period ( $\mathrm{TA}=12-14 \%$, WP $=26-34 \%$ ) and temperatures at both sites followed a similar annual pattern (Figs. 1,2). All oysters were placed on ice at collection and kept on ice for 2-5 h until hemolymph was withdrawn. Unpublished experiments have found icing of oysters to have no significant effect on the hemocyte activities described below.

In the laboratory, 12 oysters of $\geqslant 70 \mathrm{~mm}$ length were selected from each sample, notched at the posterior-ventral edge of the shell with a rock saw, and the mantle cavity drained of seawater. A syringe $\left(3 \mathrm{~cm}^{3}\right)$ with a needle $(22 \mathrm{G})$ was inserted into the adductor muscle and $\approx 0.5 \mathrm{ml}$ hemolymph drawn into the barrel. The barrel was gently 
rocked to permit hemocytes to aggregate and three or four drops of hemolymph from a single oyster were added to each of six wells of a tissue-culture plate. Each well contained $1 \mathrm{ml}$ cold $\left(4^{\circ} \mathrm{C}\right) \mathrm{Ca}$ - and $\mathrm{Mg}$-free artificial seawater (CMF) at near-ambient salinity ( $12 \%$ for TA oysters and $30 \%$ for WP oysters). Hemolymph samples from four oysters were tested at the same time in a 24 -well tissue-culture plate. The plates were placed on ice and hemocytes allowed to settle for $5 \mathrm{~min}$. The plates were then removed from the ice and $0.9 \mathrm{ml}$ cold medium drawn from each well and replaced with $\mathrm{CMF}$ at $15^{\circ} \mathrm{C}$. After $3 \mathrm{~min}$, this was withdrawn and replaced with artificial seawater at $15^{\circ} \mathrm{C}$ (ASW), each well receiving a different salinity $(6,12,18,24,30$, or $36 \%$ ). The presence of natural levels of $\mathrm{Ca}$ and $\mathrm{Mg}$ in the ASW initiated cell spreading. Description of the media CMF and ASW are detailed in Fisher \& Newell (1986a).

Hemocytes were examined with a Nikon inverted microscope $(200 \times)$ and the temperature was maintained at $15^{\circ} \mathrm{C}$ throughout the assay. Time to hemocyte spreading (THS) was measured as the length of time required after the addition of ASW for hemocytes to form ameboid shapes along the entire peripheries of the majority of hemocyte aggregates. Samples that did not exhibit locomotory cells migrating from the aggregates after $120 \mathrm{~min}$ were assigned a value of $150 \mathrm{~min}$; after $120 \mathrm{~min}$, quantification was difficult because hemocytes sometimes disaggregated but cell spreading was not distinct.

Rate of hemocyte locomotion (RHL) was measured $1-2 \mathrm{~h}$ after addition of ASW in wells containing ASW at 6,18 , and $30 \%$. A video image of the cells was projected onto a monitor and the paths of 12-15 hemocytes were traced for 5 min on a transparent plastic overlay. A computer digitizer was used to measure the paths and determine the average RHL $\left(\mu \mathrm{m} \cdot \mathrm{min}^{-1}\right)$ for each sample. Hemocytes with rates of $<0.75 \mu \mathrm{m} \cdot \min ^{-1}$ were considered immobile and those rates were deleted from calculations.

\section{LABORATORY STUDIES ON TEMPERATURE EFFECTS}

\section{Estuarine (TA) comparisons}

Oysters were collected from TA on 11 May (ambient $=18.5^{\circ} \mathrm{C}$ ) and were maintained at 15 or $25^{\circ} \mathrm{C}$ for $1 \mathrm{wk}$ in the laboratory in $50 \mathrm{I}$ aerated water $(12 \%$ salinity). 12 oysters from each holding temperature were assayed for THS at six salinities $(6-36 \%$ ) and two test temperatures $\left(15\right.$ and $\left.25^{\circ} \mathrm{C}\right)$; this required two hemolymph withdrawals from each oyster. During the assay (which was conducted on 18 May), oysters were kept on ice and tested in an order that alternated holding and test temperatures. A similar procedure was followed on $3 \mathrm{June}$ (ambient $=26.0^{\circ} \mathrm{C}$ ), except that the oysters were held for $2 \mathrm{wk}$ at 15 and $25^{\circ} \mathrm{C}$ and assayed on $17 \mathrm{June}$. In all cases, oysters held in the laboratory for $\geqslant 1$ wk were fed $2-3$ times $\cdot \mathrm{wk}^{-1}$ with 1.51 cultured Isochrysis galbani at dense concentrations. At each feeding, 201 water were exchanged.

Oysters were collected from TA on 11 May (ambient $=18.5^{\circ} \mathrm{C}$ ) and held in the laboratory at $15^{\circ} \mathrm{C}$ for $10 \mathrm{wk}$. Maintenance conditions were as described above. A 
second collection was made on 24 July (ambient $=30.2{ }^{\circ} \mathrm{C}$ ) and these oysters were held in the laboratory for $1 \mathrm{wk}$ at $25^{\circ} \mathrm{C}$ before testing. Both groups were assayed for THS on 4 August as described above, except that they were assayed at four temperatures ( 15 , 20,25 , and $30^{\circ} \mathrm{C}$ ). This required four hemolymph withdrawals from each oyster; to reduce any effects of repeated withdrawals, assays were conducted nonsequentially and oysters were kept on ice at all times. Only one or two drops of hemolymph from each oyster were used at each test temperature and only one salinity was tested (ASW $=12 \%$ ). Oysters were also collected from TA on 2 December (ambient $=9.0^{\circ} \mathrm{C}$ ) and held for $2 \mathrm{wk}$ at either 15 or $25^{\circ} \mathrm{C}$. They were assayed on 16 December at four temperatures and ambient salinity as above.

\section{Oceanic (WP) comparisons}

Oceanic oysters held in the laboratory were treated in the same manner as TA oysters, except they were maintained in $30 \%$ sea water. Oysters were collected from WP on 7 May (ambient $=18.0^{\circ} \mathrm{C}$ ) and held $1 \mathrm{wk}$ in aquaria at 15 or $25^{\circ} \mathrm{C}$. The assay was conducted on 14 May. Oysters were also collected on 8 June (ambient $=23.0^{\circ} \mathrm{C}$ ) and held 1 month at 15 and $25^{\circ} \mathrm{C}$ prior to testing on 7 July. Assays for THS were conducted at six in vitro salinities and at two temperatures, 15 and $25^{\circ} \mathrm{C}$.

Oysters from WP were also collected on 6 August (ambient $=29.1^{\circ} \mathrm{C}$ ) and on 30 October (ambient $=11.9^{\circ} \mathrm{C}$ ), held for $2 \mathrm{wk}$ in aquaria at 15 and $25^{\circ} \mathrm{C}$, and assayed for THS at four temperatures $\left(15,20,25\right.$, and $\left.30^{\circ} \mathrm{C}\right)$ as described earlier. Assays wer conducted with ASW at $30 \%$ salinity.

\section{DISEASE STATUS OF OYSTERS}

Oysters used in these assays were not examined for two major diseases that occur in Chesapeake Bay, H. nelsoni (Haskin et al., 1966) and P. marinus (Levine, 1978). However, routine sampling by the Maryland Department of Natural Resources (courtesy of D. Plutschak, Oxford Laboratory) and the Virginia Institute of Marine Sciences (courtesy of E. Burreson) outlined the disease status at TA and WP during 1987. Oysters examined from TA were native TA oysters whereas oysters examined from WP were James River, Virginia, seed introduced into Burton's Bay. Examinations for $H$. nelsoni were conducted on histological sections (Haskin et al., 1966) and for P. marinus by the fluid thioglycollate method (Ray, 1966).

\section{RESULTS}

\section{MONITORING OF ESTUARINE (TA) AND OCEANIC (WP) HABITATS}

The temperature patterns for both habitats were very similar (Figs. 1,2), with TA temperatures slightly higher than WP temperatures from May to September. In both habitats, there was a sustained increase in temperature $\left(5-20^{\circ} \mathrm{C}\right)$ from March to $\mathrm{A}$ 


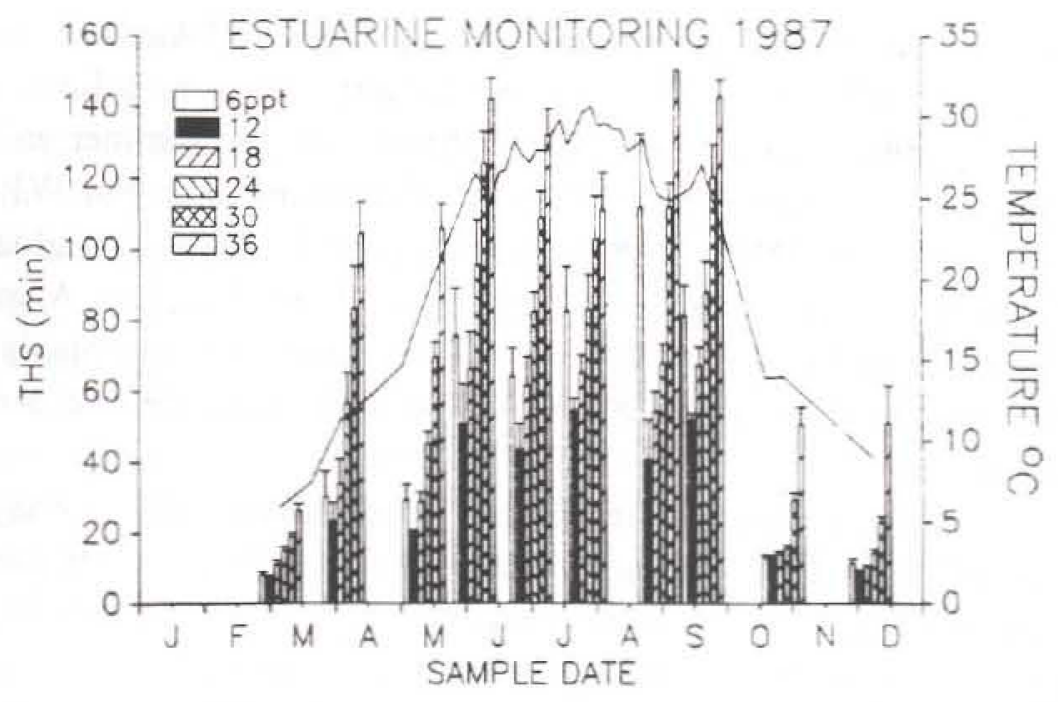

Fig. 1. Average THS values at a standard $15^{\circ} \mathrm{C}$ in vitro temperature and six in vitro salinities (keyed bars, $6-36 \%$ salinity) are shown for estuarine (TA) oysters during 1987. Hemocytes were drawn from 12 oysters at each of 10 sampling dates and subsamples were tested in all six salinities (SE bars shown, $n=12$ ). Ambient salinity of TA remained near $12 \%$ (dark bars). High THS values from spring to fall corresponded to periods of high water temperature as shown by ambient water temperatures $\left({ }^{\circ} \mathrm{C}\right)$ recorded from TA habitat.

a fluctuating "plateau" $\left(20-34^{\circ} \mathrm{C}\right)$ from June through August, and a decline $\left(20-8{ }^{\circ} \mathrm{C}\right)$ from early September into December.

Both TA- (Fig. 1) and WP-oyster hemocytes (Fig. 2) exhibited an annual cycle in time required to spread to an ameboid shape in vitro at $15^{\circ} \mathrm{C}$. THS values at ambient salinities (dark bars in Figs. 1, 2) were higher in both habitats during the summer months

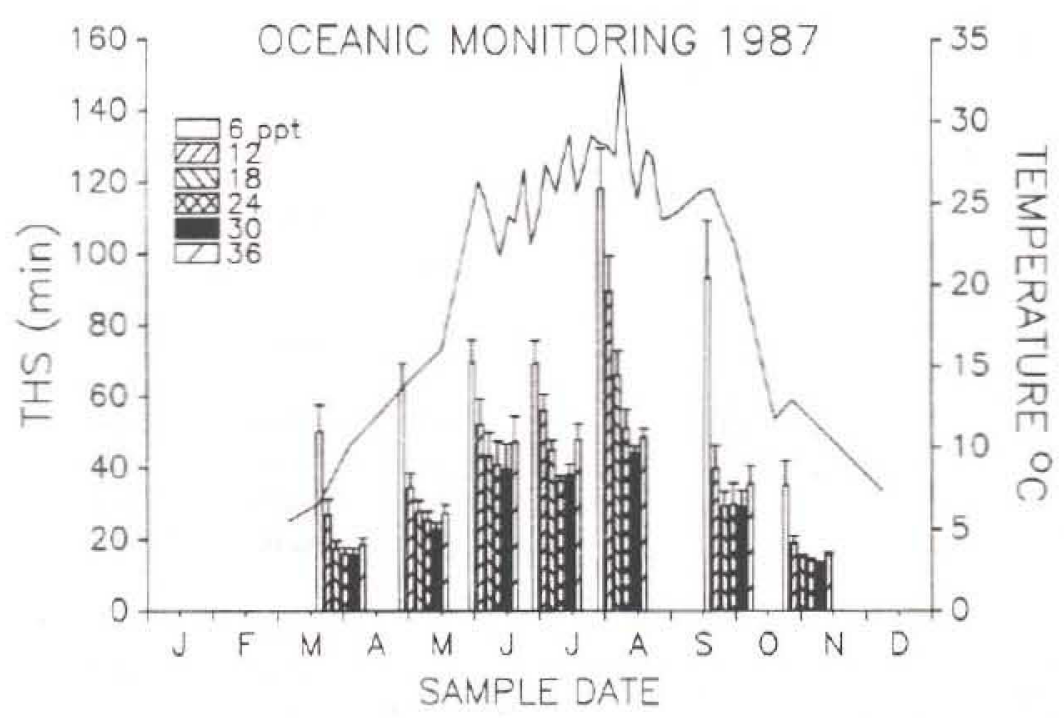

Fig. 2. Average THS values at a standard $15^{\circ} \mathrm{C}$ in vitro temperature and six in vitro salinities (keyed bars, $6-36 \%$ salinity) are shown for oceanic (WP) oysters during 1987. Hemocytes were drawn from 12 oysters at each of seven sampling dates and subsamples were tested in all six salinities (SE bars shown, $n=12$ ). Ambient salinity of WP remained near $30 \%$ (dark bars). High THS values during summer corresponded to periods of high water temperature as shown by ambient water temperatures $\left({ }^{\circ} \mathrm{C}\right)$ recorded from WP habitat. 
and lower in late fall, winter, and early spring. For TA-oyster hemocytes, there was an increase in THS at the ambient test salinity $(12 \%)$ by 3 June. Ambient-salinity THS remained nearly level at $40-50$ min throughout the summer and early autumn for TA oysters but decreased at the 23 October sampling date. For WP-oyster hemocytes, the annual cycle of THS at ambient salinity $(30 \%$ ) was more gradual (dark bars in Fig. 2). The highest THS values were recorded in June, July, and August, with a decrease in September and October. Kruskal-Wallis analysis found highly significant differences between collection dates $(P<0.01)$ for both estuarine and oceanic THS at ambient salinities.

THS after an acute in vitro change from ambient salinity was increased for nearly all samples, regardless of habitat or sample date (Figs. 1,2). Higher in vitro test salinities increased THS proportionally (Fig. 1). Lower test salinities for WP-oyster hemocytes caused a consistent increase in THS at only the $6 \%$ test salinity; however, during the summer months there was also an increase in THS at 12 and 18\%o (Fig. 2).

Data from in vitro salinity changes were used to calculate the time required for hemocytes to salinity regulate (TSR) by subtracting ambient-salinity THS from testsalinity THS and dividing by the difference in salinity. This value designates the time

\section{TABLE I}

Time for salinity regulation for Tred Avon River and Wachapreague oyster hemocytes sampled at dates indicated and measured at salinities from 6 to $36 \%$. Formula for obtaining these values is given in text. This describes time required for hemocytes to adjust to a $1 \%$ salinity increase or decrease from ambient $\left(\mathrm{min} \cdot 1 \%^{-1}\right.$ salinity) at $15^{\circ} \mathrm{C}$. Ambient (amb.) temperature for each collection date is noted. Ambient salinity was $\approx 12 \%$ for TA and $\approx 30 \%$ for WP at all sample dates.

\begin{tabular}{lcrrrrrr}
\hline $\begin{array}{l}\text { Sample } \\
\text { date }\end{array}$ & $\begin{array}{c}\text { Ambient } \\
\text { temperature } \\
\left({ }^{\circ} \mathrm{C}\right)\end{array}$ & \multicolumn{7}{c}{ Test salinity (\%) } \\
\cline { 3 - 8 } & & 6 & 12 & 18 & 24 & 30 & 36 \\
\hline Tred Avon River & & & & & & & \\
06 Mar & 6.0 & 0.2 & Amb. & 0.6 & 0.7 & 0.7 & 0.8 \\
04 Apr & 11.4 & 1.1 & Amb. & 1.8 & 2.8 & 3.3 & 3.4 \\
11 May & 18.5 & 1.6 & Amb. & 1.5 & 2.1 & 2.8 & 3.6 \\
03 Jun & 21.0 & 4.1 & Amb. & 2.6 & 3.7 & 4.1 & 3.8 \\
29 Jun & 27.0 & 3.4 & Amb. & 3.0 & 3.3 & 3.6 & 3.7 \\
24 Jul & 31.0 & 4.7 & Amb. & 1.8 & 2.4 & 2.7 & 2.4 \\
27 Aug & 25.1 & 11.8 & Amb. & 2.2 & 2.3 & 3.9 & 4.6 \\
16 Sep & 27.0 & 5.0 & Amb. & 2.6 & 3.0 & 3.8 & 3.8 \\
23 Oct & 14.0 & 0.1 & Amb. & 0.2 & 0.2 & 0.9 & 1.6 \\
02 Dec & 9.0 & 0.4 & Amb. & 0.2 & 0.4 & 0.8 & 1.7 \\
Wachapreague & & & & & & & \\
30 Mar & 12.5 & 1.4 & 0.6 & 0.1 & $<0.1$ & Amb. & 0.5 \\
07 May & 18.0 & 1.6 & 0.6 & 0.4 & 0.4 & Amb. & 0.7 \\
08 Jun & 23.2 & 1.2 & 0.7 & 0.3 & 0.2 & Amb. & 1.3 \\
07 Jul & 25.6 & 1.3 & 1.0 & 0.6 & 0.3 & Amb. & 1.6 \\
06 Aug & 29.1 & 3.1 & 2.5 & 1.8 & 1.1 & Amb. & 0.7 \\
24 Sep & 21.2 & 2.7 & 0.6 & $<0.1$ & 0.1 & Amb. & 1.0 \\
30 Oct & 11.9 & 0.9 & 0.3 & 0.2 & 0.1 & Amb. & 0.4 \\
\hline
\end{tabular}


required $(\mathrm{min})$ for hemocytes to adjust to an acute $1 \%$-salinity increase or decrease from ambient (Table I). For TA-oyster hemocytes, TSR to higher salinities was $\approx 1 \mathrm{~min} \cdot 1 \%^{-1}$ salinity in March, October, and December but as high as $4 \mathrm{~min} \cdot 1 \%{ }^{-1}$ in the summer months. Reduction to $6 \%$ test salinity increased TSR from $0.2 \mathrm{~min} \cdot 1 \%^{-1}$ in March to $11.8 \mathrm{~min} \cdot 1 \%^{-1}$ at the end of August, then declined to low values again for the October and December samples. For WP oysters, TSR after reduction to 24 and $18 \%$ test salinities was consistently low $\left(\leq 0.6 \mathrm{~min} \cdot 1 \%{ }^{-1}\right)$ for all but the August sample. Reduction to 12 and $6 \%$ test salinities increased TSR proportionally, with the highest TSR in August at $6 \%$ o test salinity. Test salinities of $36 \%$ for WP-oyster hemocytes increased TSR to a peak in July.

RHL monitored from TA oysters showed a consistent pattern in response to acute in vitro changes in salinity (Fig. 3a); hemocytes were faster at $6 \%$ salinity and slower at $30 \%$. Variations in RHL were significantly different between dates of collection (Kruskal-Wallis, $P<0.01$ ) at each salinity but did not appear to follow a seasonal

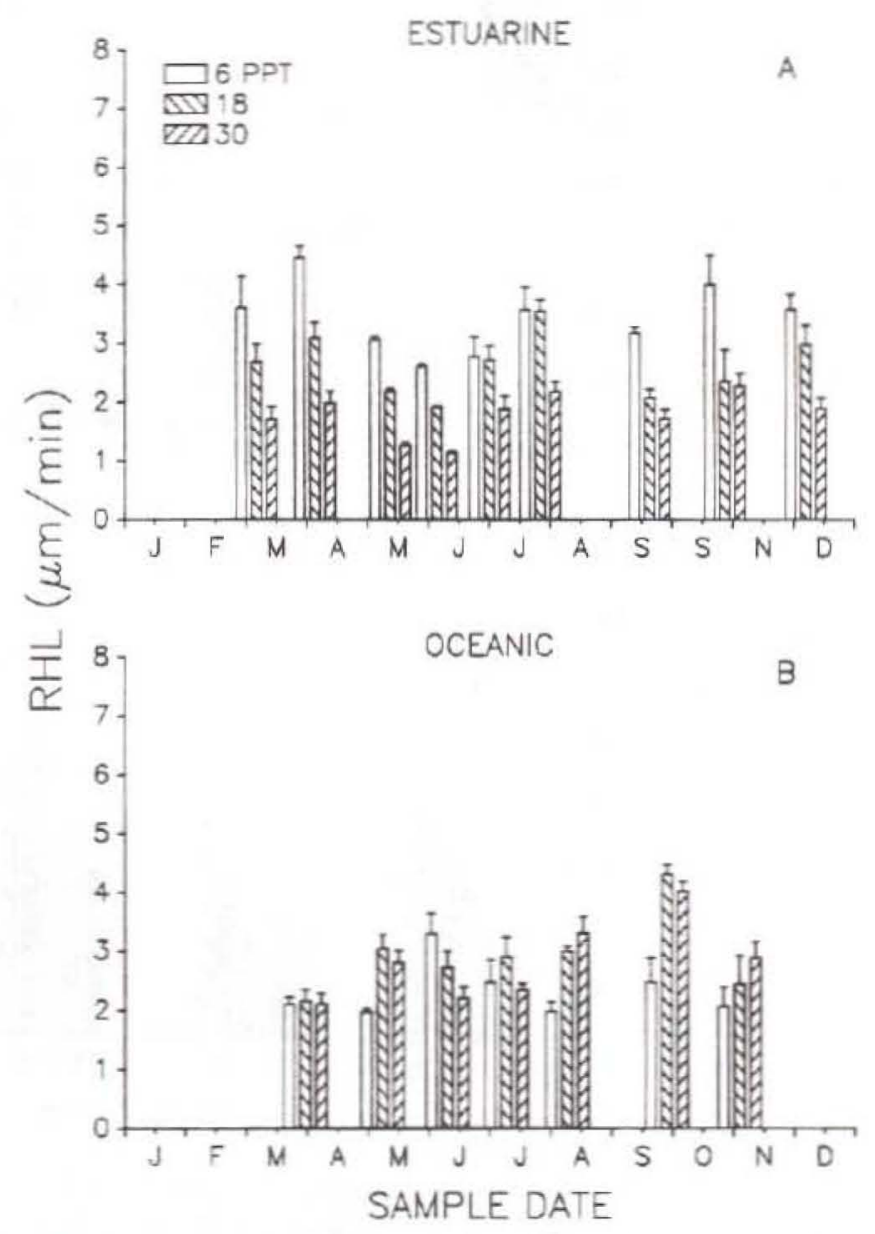

Fig. 3. Average RHL values for estuarine oysters (A) and oceanic oysters (B) assayed at three in vitro salinities $(6,18$, and $30 \%$ ) are shown for oyster samples collected in 1987. Ambient salinity for TA habitat was $12 \%$ and for WP habitat was $30 \%$. Locomotion assays were conducted at $15^{\circ} \mathrm{C}$ within $90 \mathrm{~min}$ of hemocyte spreading. SE bars are shown $(n=12)$. 
trend. Likewise, RHL from WP oysters were significantly different between collection dates at each salinity but did not exhibit a seasonal trend (Fig. 3b). Acute in vitro decreases from ambient salinity $(30 \%$ ) did not consistently alter RHL for WP oysters.

\section{LABORATORY STUDIES ON TEMPERATURE EFFECTS}

\section{Estuarine (TA) comparisons}

Two-way ANOVA on TA oysters collected on 11 May revealed no differences $(P>0.05)$ in THS at ambient salinity $(12 \%)$ between oysters held for 1 wk at 15 or $25^{\circ} \mathrm{C}$ and assayed at both temperatures (Fig. 4a) but there was a pattern of increasing THS with increased in vitro test salinity. Oysters collected from TA in the summer



Fig. 4. Average THS values are shown for estuarine oysters (TA) at six different in vitro salinities (see key, $6-36 \%$ ). Ambient salinity was $12 \%$ (dark bars). (A) Oysters were collected on 11 May (ambient temperature $=18.5^{\circ} \mathrm{C}$ ) and maintained in aquaria at holding temperatures of either 15 or $25^{\circ} \mathrm{C}$ for 1 wk prior to assay. (B) Oysters were collected on $3 \mathrm{June}$ (ambient temperature $=26.0^{\circ} \mathrm{C}$ ) and maintained at 15 or $25^{\circ} \mathrm{C}$ for 2 wk prior to assay. In both cases, hemocytes were tested in vitro at 15 and $25^{\circ} \mathrm{C}$. SE bars are shown

$$
(n=12) \text {. }
$$




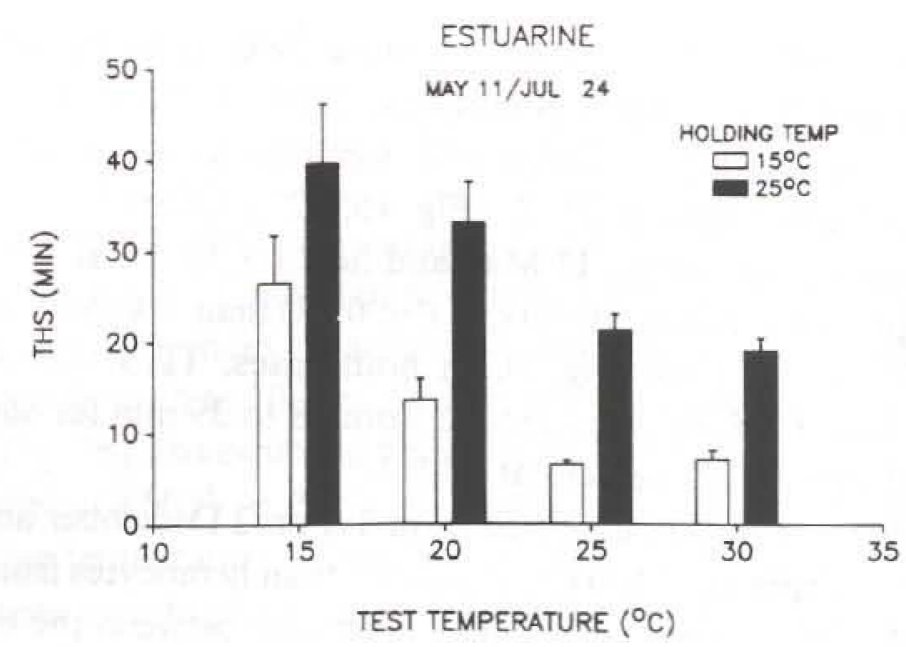

Fig. 5. Average THS values are shown for estuarine oysters (TA) at four in vitro test temperatures (15, 20, 25 , and $30^{\circ} \mathrm{C}$ ). A sample of oysters was collected on 11 May (ambient temperature $=18.5^{\circ} \mathrm{C}$ ) and held in an aquarium for $10 \mathrm{wk}$ at $15^{\circ} \mathrm{C}$ (open bars). A second sample of oysters was collected on $24 \mathrm{July}$ (ambient temperature $=30.2^{\circ} \mathrm{C}$ ) and held in an aquarium for $1 \mathrm{wk}$ at $25^{\circ} \mathrm{C}$ (dark bars). Both samples were assayed for THS at an in vitro salinity of $12 \%$ on 4 August. SE bars are shown $(n=12)$.

( 3 June) and held for 2 wk at 15 and $25^{\circ} \mathrm{C}$ exhibited highly significant differences (ANOVA, $P<0.01$ ) in THS at ambient salinity, with significant variation stemming from both holding and test temperatures (Fig. 4b). The lowest THS values, regardless of test salinity, were from hemocytes held at $15^{\circ} \mathrm{C}$ and tested at $25^{\circ} \mathrm{C}$ whereas the highest THS values were from those held at $25^{\circ} \mathrm{C}$ and tested at $15^{\circ} \mathrm{C}$. Hemocytes from oysters collected in the spring (Fig. 4a) had a lower ambient THS than those from oysters collected in the summer (Fig. 4b), under all holding and test conditions

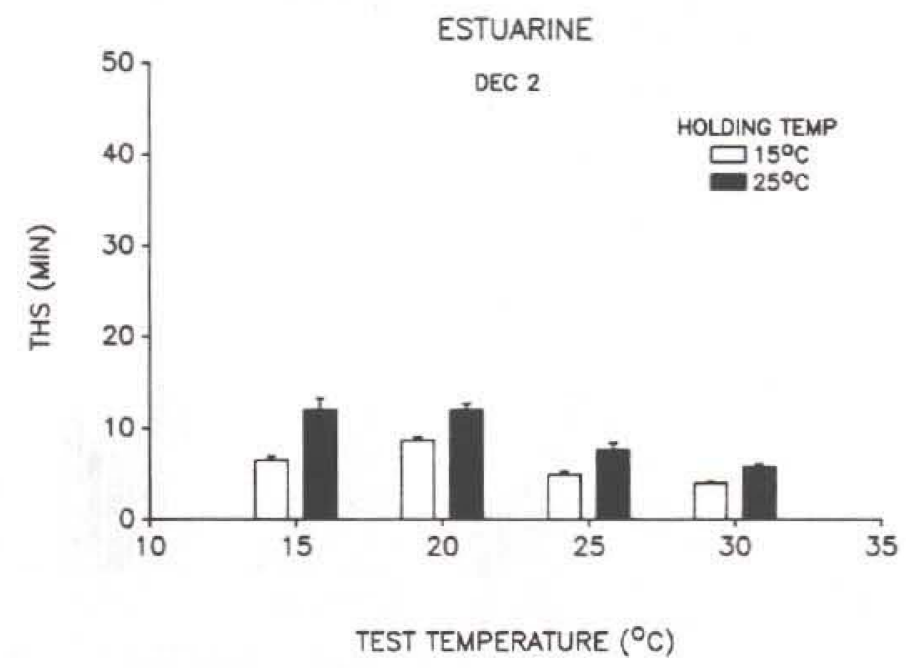

Fig. 6. Average THS values are shown for estuarine oysters (TA) at four in vitro test temperatures $(15,20$, 25 , and $30^{\circ} \mathrm{C}$ ). Oysters were collected on 2 December (ambient temperature $=9.0^{\circ} \mathrm{C}$ ) and maintained in aquaria at holding temperatures of either $15^{\circ} \mathrm{C}$ (open bars) or $25^{\circ} \mathrm{C}$ (dark bars) for 2 wk prior to assay. 12 oysters from each holding temperature were assayed at $12 \%$ in vitro salinity on 16 December. SE bars are shown $(n=12)$. 
(Student's $t$ tests, $P<0.05$ ), except those held at $15^{\circ} \mathrm{C}$ and tested at $25^{\circ} \mathrm{C}$. In a comparison of near-ambient conditions, THS for the 11 May sample held and tested at $15^{\circ} \mathrm{C}$ (Fig. $4 \mathrm{a}, 12 \%$ salinity) was significantly lower $(P<0.01)$ than the 3 June sample held and tested at $25^{\circ} \mathrm{C}$ (Fig. 4b, $12 \%$ salinity).

TA oysters collected on $11 \mathrm{May}$ and held for $10 \mathrm{wk}$ at $15^{\circ} \mathrm{C}$ were faster to spread at all temperatures tested (ANOVA, $P<0.01$ ) than TA oysters collected on 24 July and kept at $25^{\circ} \mathrm{C}$ for 1 wk (Fig. 5). In both cases, THS was reduced with higher test temperatures. THS averages ranged from 18 to $39 \mathrm{~min}$ for samples held at $25^{\circ} \mathrm{C}$ and from 5-26 min for those held at $15^{\circ} \mathrm{C}$.

Hemocytes of oysters collected from TA on 2 December and held at $15^{\circ} \mathrm{C}$ for $2 \mathrm{wk}$ were faster to spread (ANOVA, $P<0.01$ ) than hemocytes from the same oyster sample held at $25^{\circ} \mathrm{C}$ for $2 \mathrm{wk}$ (Fig. 6). The difference between the two was only $5 \mathrm{~min}$ at its greatest.

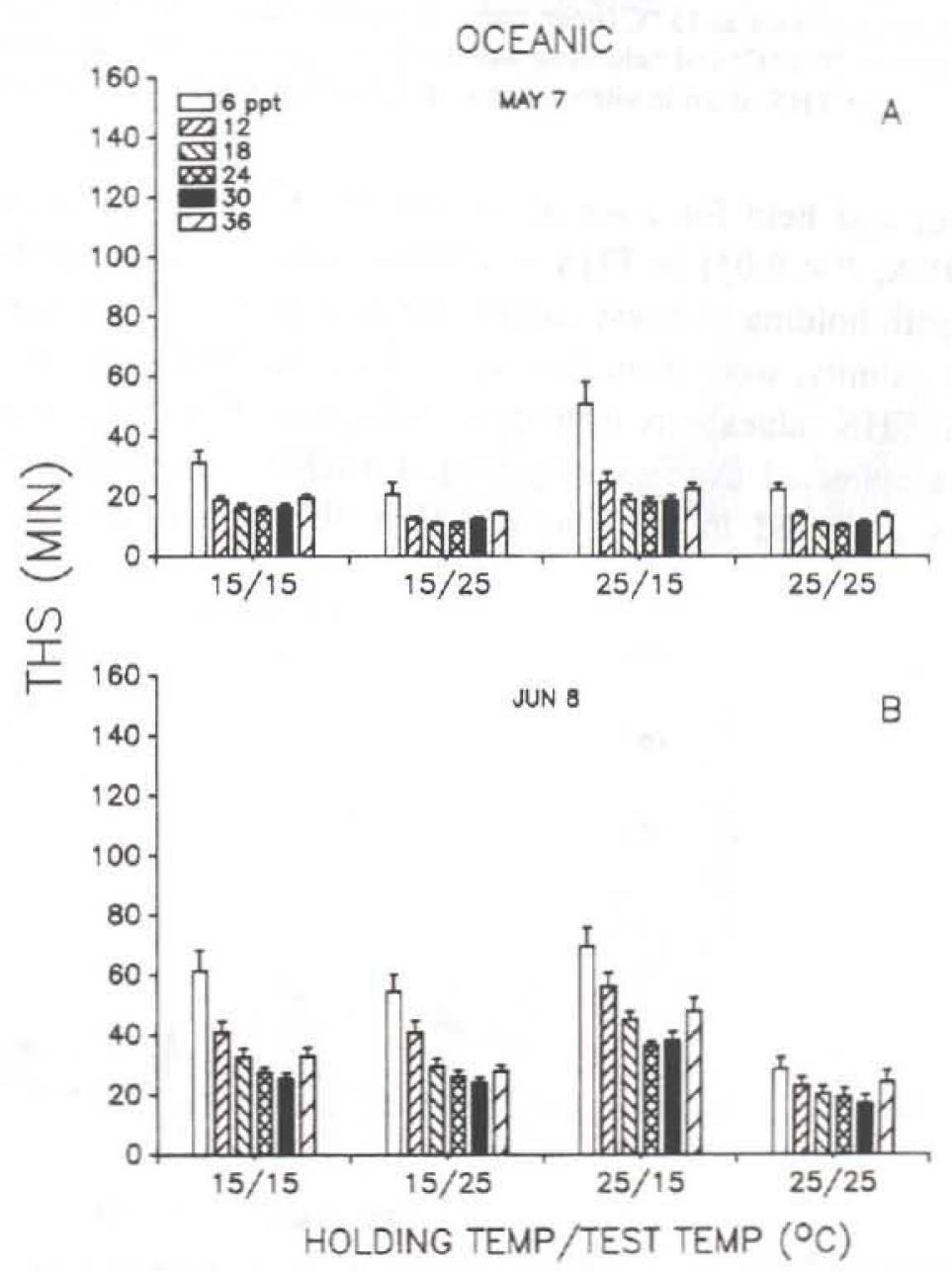

Fig. 7. Average THS values are shown for oceanic oysters (WP) at six different in vitro salinities (see key, 6-36\%). Ambient salinity was $30 \%$ (dark bars). (A) Oysters were collected on 7 May (ambient temperature $=18.0^{\circ} \mathrm{C}$ ) and maintained in aquaria with holding temperatures of either 15 or $25^{\circ} \mathrm{C}$ for 1 wk prior to assay. (B) Oysters were collected on $8 \mathrm{June}$ (ambient temperature $=23.0^{\circ} \mathrm{C}$ ) and maintained at either 15 or $25^{\circ} \mathrm{C}$ for 1 month prior to assay. In both cases, hemocytes were tested in vitro at 15 and $25^{\circ} \mathrm{C}$. SE bars are shown $(n=12)$. 


\section{Oceanic (WP) comparisons}

Oysters collected from WP on 7 May and held 1 wk at 15 or $25^{\circ} \mathrm{C}$ before the hemocytes were tested in vitro at 15 and $25^{\circ} \mathrm{C}$ showed highly significant differences (ANOVA, $P<0.01$ ) in ambient-salinity $(30 \%$ ) THS (Fig. 7a). This was entirely due to a lower THS at the $25^{\circ} \mathrm{C}$ test temperature, regardless of holding temperature. The magnitude of the differences at ambient salinity was $<5 \mathrm{~min}$ in all cases and THS averages ranged from 10 to $20 \mathrm{~min}$. Oysters collected on 8 June and held at 15 or $25^{\circ} \mathrm{C}$ for 1 month (Fig. 7b) also exhibited highly significant differences between the treatments at ambient salinity (ANOVA, $P<0.01$ ). Again, significance was due to test temperature and not holding temperature although there was an interaction effect. The magnitude of the differences at ambient salinity was $20 \mathrm{~min}$ at its greatest and THS averages ranged from 20 to $40 \mathrm{~min}$.

In all treatments (Fig. 7), the hemocytes of oysters collected on 7 May were faster to spread at ambient salinity than hemocytes from oysters collected on 8 June ( $t$ tests,

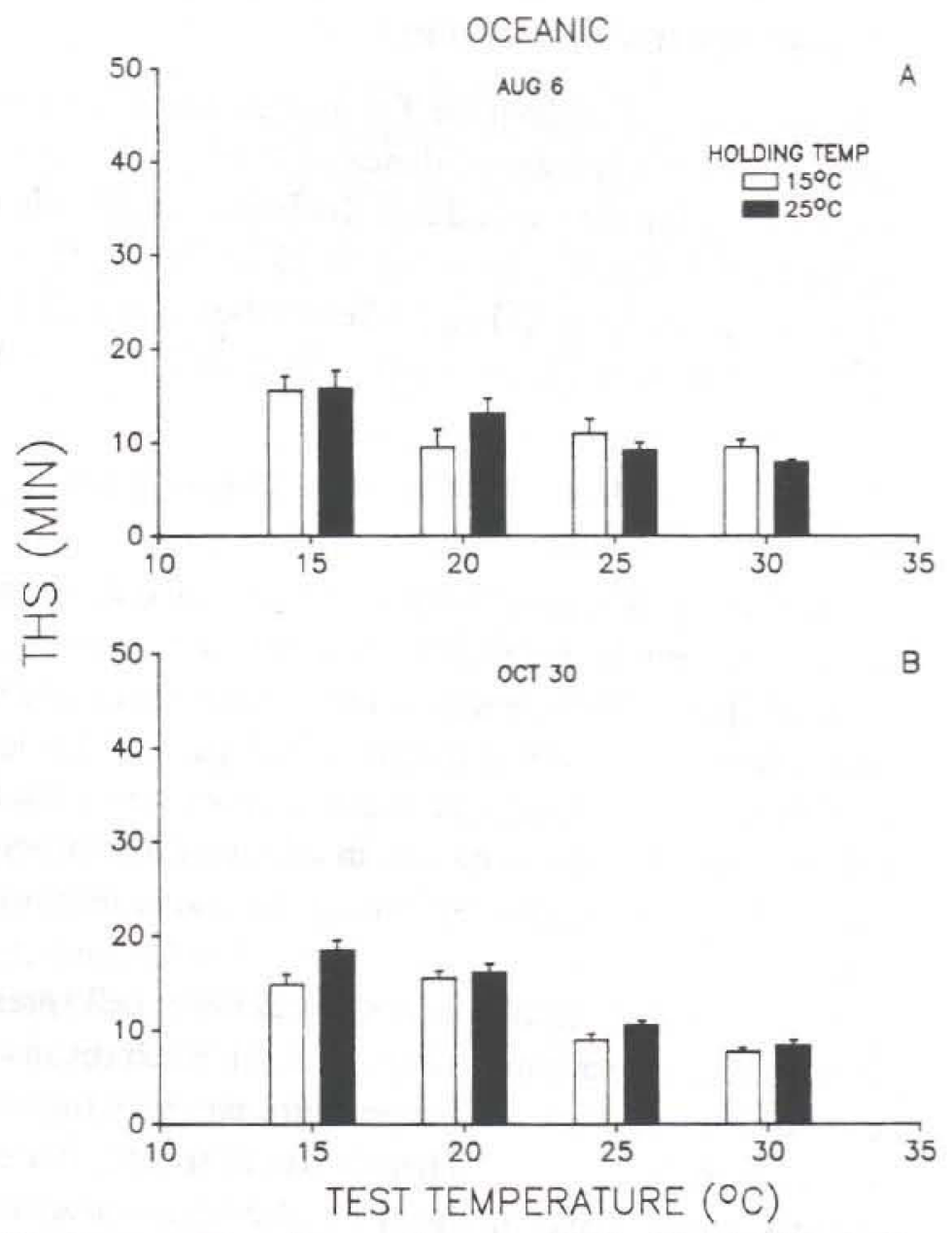

Fig. 8. Average THS values are shown for oceanic oysters (WP) at four in vitro test temperatures $(15,20$, 25 , and $30^{\circ} \mathrm{C}$ ). (A) Oysters were collected on 6 August (ambient temperature $=29.1^{\circ} \mathrm{C}$ ). (B) Oysters were collected on 30 October (ambient temperature $=11.9^{\circ} \mathrm{C}$ ). In both cases, oysters were maintained in aquaria at holding temperatures of either 15 or $25{ }^{\circ} \mathrm{C}$ for $2 \mathrm{wk}$ prior to in vitro testing at $30 \%$ salinity. SE are shown 
$P<0.05$ ). In a comparison of near-ambient conditions, there was no difference between 7 May oysters held and tested at $15^{\circ} \mathrm{C}$ (Fig. 7a) and 8 June oysters held and tested at $25^{\circ} \mathrm{C}$ (Fig. 7b). In both samples and at all treatments, there was an increased THS at 6 and $36 \%$ test salinities. In the 7 May sample, THS for test salinities of $18-30 \%$ were nearly the same, regardless of holding and test temperature. In the 8 June sample, there was a proportional increase in THS for all treatments as test salinities were reduced.

Oysters collected from WP on 6 August (Fig. 8a) and held for 2 wk at 15 or $25^{\circ} \mathrm{C}$ showed a significant difference between treatments (ANOVA, $P<0.01$ ) due entirely to lower THS at higher test temperatures. There were no significant differences between holding temperatures when tested at the same temperature ( $t$ test, $P>0.05$ ). Oysters collected on 30 October (Fig. 8b) showed a significant difference between treatments (ANOVA, $P<0.01$ ) due to both holding and test temperatures. Further analysis showed the $15^{\circ} \mathrm{C}$ holding temperature to be significantly faster $(t$ test, $P<0.05)$ than the $25^{\circ} \mathrm{C}$ holding temperature when tested at $15^{\circ} \mathrm{C}$.

\section{DISEASE STATUS OF OYSTERS}

Incidence of $H$. nelsoni for TA oysters was $2 \%(n=30)$ on $30 \mathrm{July}$ and $0 \%(n=30)$ on 19 October whereas incidence of $P$. marinus was $20 \%(n=30)$ and $28 \%(n=30)$, respectively, for the same dates. Incidence of $H$. nelsoni on James River oysters introduced to WP was $0 \%(n=50)$ on 15 April, $4 \%(n=25)$ on 3 June, $17 \%(n=24)$ on 24 August, $12 \%(n=25)$ on 29 September, and $20 \%(n=25)$ on 29 October. Incidence of P. marinus was $0 \%(n=25)$ at WP on 29 September.

\section{DisCUSSION}

Monitoring of oyster hemocytes demonstrated high annual variation and a cyclic annual pattern in hemocyte capacity to spread to an ameboid shape in vitro at a standard $\left(15^{\circ} \mathrm{C}\right)$ temperature. This activity was rapid in late fall, winter, and early spring and slow from late spring to early fall (Figs. 1, 2, Table I), a pattern which corresponded with the annual temperature cycle. This was recorded for hemocytes assayed at ambient salinity and after acute changes in salinity. Laboratory studies confirmed the suppressed rate of hemocyte spreading during the warm seasons (for example, cf. Figs. $4 \mathrm{a}$ vs. $4 \mathrm{~b}$ and $7 \mathrm{a}$ vs. $7 \mathrm{~b})$.

Yet, laboratory studies also showed faster cell spreading (decreased THS) at warmer in vitro test temperatures (Figs. 5, 6, 8). Such results demonstrated relative differences due to acute changes in temperature whereas the monitoring assays reflected annual variation in the potential of hemocytes to spread. For example, hemocytes from estuarine oysters spread faster at higher in vitro temperatures for both mid-summer (Fig. 5) and winter (Fig. 6) samples but the winter sample, by virtue of its shorter spreading times at all temperatures, exhibited a greater spreading potential. A greater spreading potential does not necessarily mean that oyster hemocytes spread faster in winter under natur 
conditions; ambient water temperatures must also be expected to influence in situ spreading.

The most plausible explanation for reduced hemocyte potential during summer months is physiological stress. Bayne (1975) suggested that stress is an environmental condition that lessens the ability of an organism (or cell) to respond to other changes in the environment. Hemocyte spreading after acute salinity changes, acute temperature changes, and various holding temperatures were retarded during the summer (Table I, Figs. $4 \mathrm{~b}, 5,7 \mathrm{~b}$ ). This implies that environmental conditions in the summer affected the hemocytes in a manner that reduced their ability to respond to temperature and salinity changes. Measurement of physiological parameters during stress can uncover factors that are not detectable during nonstress but may nonetheless be vital to the survival of the organism.

Differences between ambient temperature and the in vitro $\left(15^{\circ} \mathrm{C}\right)$ assay temperature may have contributed to the cyclic nature of the monitoring results. Reduced activity might have occurred when hemocytes from higher ambient temperatures were assayed at $15^{\circ} \mathrm{C}$. Conversely, activity may have increased for hemocytes from lower ambient temperatures. Implicit in this argument, however, is that hemocytes were: (1) predisposed to a specific rate of activity defined by the ambient temperature; and (2) this rate was retained by the hemocytes through several hours on ice during oyster transit to the laboratory and sample preparation. If ambient temperatures defined a specific rate of hemocyte activity, then different holding temperatures should have altered that rate. Yet, cell activities were influenced by holding temperatures only during the summer-stress period (Figs. 5, 7b). Holding temperature had no effect on spring and early summer TA oysters (Fig. 4) or on spring, fall, and winter WP oysters (Figs. 7a, $8 \mathrm{a}, \mathrm{b})$. A comparison of THS (Fig. 1) and TSR (Table I) from oysters sampled when ambient temperatures were near $15^{\circ} \mathrm{C}$ (for example, 23 October, 4 April, and 11 May from TA) supports the contention that the annual cycle in hemocyte potential demonstrated in this study was not a consequence of short-term or acute temperature changes.

Although in vitro measurement at a standard temperature $\left(15^{\circ} \mathrm{C}\right)$ excluded most comparisons of activity at ambient temperatures, some comparisons can be made. Hemocytes from spring WP oysters (Fig. 7a) were faster to spread than hemocytes from summer WP oysters (Fig. 7b), regardless of the holding and test temperature. The same was true in all but one case for hemocytes from spring and summer TA oysters (Fig. 4a,b). In fact, hemocytes from spring TA oysters (ambient temperature $=19^{\circ} \mathrm{C}$ ) held and tested at $15^{\circ} \mathrm{C}$ were faster to spread than those from summer oysters (ambient temperature $=26^{\circ} \mathrm{C}$ ) held and tested at $25^{\circ} \mathrm{C}$ (Fig. 4). In addition to the decreased summertime capacity to respond at a standardized test temperature, this limited data set shows that hemocyte activities were also retarded under ambient-temperature conditions during the summer.

Summer stress for TA oyster hemocytes could have occurred in two separate stages: one between March and April and a second between May and June (Fig. 1, Table I). If so, it is possible that the first was caused by increasing temperature (Fig. 1) and the 
second by stress from spawning which was noted in TA during the 1st wk of June and continued throughout the summer (S. Alspach, Western Maryland College, pers. comm.). Similarly, WP samples showed an increased TSR for all acute salinity reductions in the 6 August sample, soon after the peak spawning period for WP oysters (M. Castagna, Virginia Institute of Marine Science, pers. comm.). Hemolymph levels of protein and carbohydrate reach a peak in oysters prior to spawning and drop precipitously thereafter (Fisher \& Newell, 1986b).

Although both THS and TSR were higher during the summer months, it is not clear that the same mechanisms were affected. The ratios of test-salinity THS to ambientsalinity THS (Fig. 9) indicate that salinity regulation was not consistently proportional to the ambient-salinity THS. In fact, the ratio declines during the summer for both TA

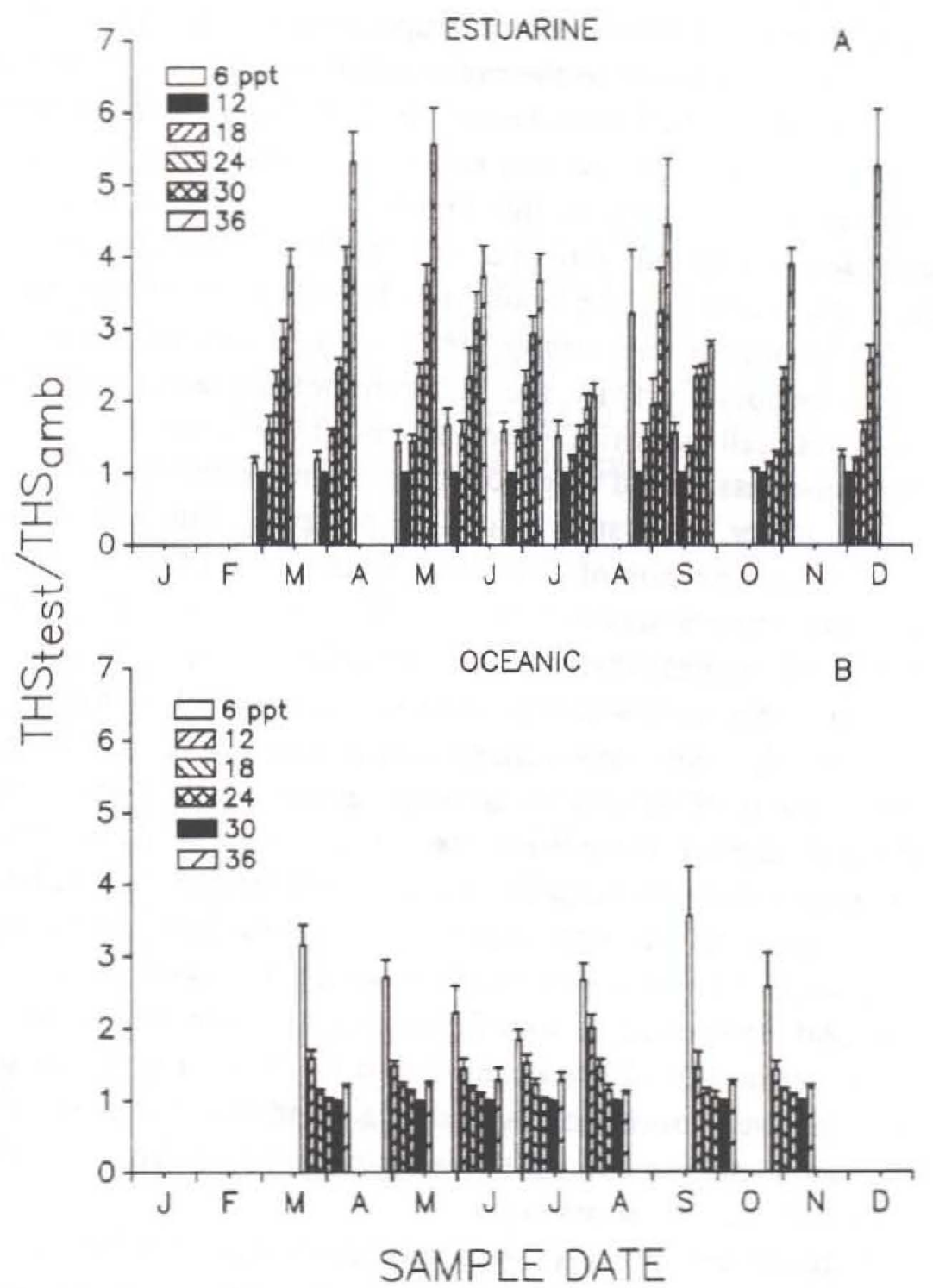

Fig. 9. Ratios of test-salinity THS to ambient-salinity THS are shown for estuarine oysters (A) and oceanic oysters (B) monitored in 1987 . Subsamples of hemocytes tested at ambient salinities (12\%。 for estuarine and $30 \%$ for oceanic samples) yielded, by definition, a ratio of 1 (dark bars). SE bars are shown $(n=12)$. 
and WP samples, indicating a greater stress on cell spreading than salinity regulation. The lack of cyclic differences in the rate of hemocyte locomotion (Fig. 3) also indicates some specificity to the cellular mechanisms affected. Although cell spreading is requisite for locomotion, it is not necessarily affected by the same environmental stressors; in a recent study (Fisher et al., in press), high in vitro doses of tributyltin inhibit RHL of oyster hemocytes but do not affect THS.

Increased THS after an acute salinity change is probably due to the need for cells to avoid major changes in size (volume regulation) before normal physiological processes, such as cell spreading, can occur. These and previous studies (Fisher \& Newell, 1986a; Fisher \& Tamplin, 1988) showed that hyperosmotic conditions increased THS whereas hypoosmotic conditions did not alter THS unless reduced to the lowest salinities (6-12\%o). Generally, more time is consumed when oyster hemocytes must adjust to higher than to lower salinities. This has also been found in Modiolus demissus where intracellular biochemical changes stabilize within hours in hypoosmotic conditions (Pierce, 1970) but require weeks in hyperosmotic conditions (Baginski \& Pierce, 1975). Summer stress, however, greatly retarded hypoosmotic adjustment: TSR from 12 to $6 \%$ for TA oyster hemocytes on 27 August required $11.8 \mathrm{~min}$ for each $1 \%$ 。 reduction in salinity (Table I). All changes in salinity, increase or decrease, caused a higher TSR in the summer and early fall than at any other time of the year (Table I).

These results clearly indicate an annual cycle in the potential of hemocytes to perform certain activities. Since these activities are requisite for hemocyte function in oyster internal defense (Fisher, 1988b), it is important that their capacity decreases during the summer when parasite activity is at its peak. Both H. nelsoni (Haskin et al., 1966) and $P$. marinus (Levine, 1978), disease agents of $C$. virginica, inflict the greatest damage to oyster populations during the warm summer and fall months. It is possible that infection by these diseases influenced the hemocyte activities measured in this study, but diseasemonitoring programs conducted by the Virginia Institute of Marine Science and the Maryland Department of Natural Resources found low disease incidence in TA and WP in 1987.

Hemocytes are important in bivalve defense and their cyclic pattern of activity may have an effect on disease incidence. But hemocytes can also reflect the physiological condition of other cells in the animal. Because oysters are poikilothermic and osmoconforming, all cells and tissues are potentially influenced by temperature and salinity in the same manner. Thus, these hemocyte assays may indicate an overall decrease in oyster vitality during the summer which could contribute to their increased disease susceptibility.

\section{ACKNOWLEDGEMENTS}

We thank D. Feeney and L. Gale for their technical assistance and M. Castagna, Virginia Institute of Marine Science, for providing oceanic oysters. This work is a result of research sponsored in part by NOAA Office of Sea Grant, Department of Commerce, under Grant NA86AA-D-SG006. 
Acton, R.T. \& E. E. Evans, 1968. Bacteriophage clearance in the oyster (Crassostrea virginica). J. Bacteriol., Vol 95. pp. $1260-1266$

Andrews, J. D., 1984. Epizootiology of diseases of oysters (Crassostrea virginica) and parasites of associated organisms in eastern North America. Helgol. Meeresunters., Vol. 37, pp. 149-166.

Baginski, R.M. \& S.K. Pierce, 1975. Anaerobiosis: a possible source of osmotic solute for high-salinity acclimation in marine molluscs. J. Exp. Biol., Vol. 62, pp. 589-598.

Bayne, B. L., 1975. Aspects of physiological condition in Mytilus edulis L. with special reference to the effects of oxygen tension and salinity. In, Proc. 9th Eur. Mar. Biol. Symp., edited by H. Barnes, Aberdeen University Press, Aberdeen, pp. 213-238.

Cheng, T. C., 1981. Bivalves. In, Invertebrate blood cells, edited by N. A. Radcliffe \& A. F. Rowley, Academic Press, New York, pp. 233-300.

Chu, F,-L.E. \& K.H. Greene, in press. Effect of temperature and salinity on in vitro culture of the oyster pathogen, Perkinsus marinus (Apicomplexa; Perkinsea). J. Invertebr. Pathol.

Feng, J.S., 1966. The fate of a virus, Staphylococcus aureus phage 80, injected into the oyster, Crassostrea virginica. J. Invertebr. Pathol., Vol. 8, pp. 496-504.

Feng, S. Y., 1966. Experimental bacterial infections in the oyster, Crassostrea virginica. J. Invertebr. Pathol., Vol. 8, pp. 505-511.

Feng, S. Y. \& J.S. Feng, 1974. The effect of temperature on cellular reactions of Crassostrea virginica to the injection of avian erythrocytes. J. Invertebr. Pathol., Vol. 23, pp. 22-37.

Feng, S.Y., J.S. Feng \& T. Yamasu, 1977. Roles of Mytilus coruscus and Crassostrea gigas blood cells in defense and nutrition. In, Comparative pathobiology, Vol. 3: Invertebrate immune responses, edited by L. A. Bulla, Jr. \& T.C. Cheng, Plenum, New York, pp. 31-67.

Fisher, W.S., 1986. Structure and functions of oyster hemocytes. In, Immunity in invertebrates, edited by M. Brehelin, Springer-Verlag, Berlin, pp. 25-35.

Fisher, W.S., 1988a. In vitro binding of parasites (Bonamia ostreae) and latex particles by hemocytes of susceptible and insusceptible oysters. Dev. Comp. Immunol., Vol. 12, pp. 43-53.

Fisher, W. S., 1988b. Environmental influence on bivalve hemocyte function. In, Disease processes in marine bivalve molluscs, edited by W.S. Fisher, Am. Fish. Soc. Spec. Publ., No. 18, pp. 225-237.

Fisher, W. S., M. Auffret \& G. Balouet, 1987. Acclimation of European flat oyster (Ostrea edulis) hemocytes to acute salinity and temperature changes. Aquaculture, Vol. 67, pp. 179-190.

Fisher, W.S. \& R.I.E. Newell, 1986a. Salinity effects on the activity of granular hemocytes of American oysters, Crassostrea virginica. Biol. Bull. (Woods Hole, Mass.), Vol. 170, pp. 122-134.

Fisher, W.S. \& R. I. E. Newell, 1986b. Seasonal and environmental variation in protein and carbohydrate levels in the hemolymph from American oysters (Crassostrea virginica Gmelin). Comp. Biochem. Physiol., Vol. 85 A, pp. 365-372.

Fisher, W.S. \& M. Tamplin, 1988. Environmental influence on activity and foreign-particle binding by hemocytes of American oysters, Crassostrea virginica. Can. J. Fish. Aquat. Sci., Vol. 45, pp. 1309-1315.

Foley, D.A. and T.C. Cheng, 1975. A quantitative study of phagocytosis by hemolymph cells of the pelecypods Crassostrea virginica and Mercenaria mercenaria. J. Invertebr. Pathol., Vol. 25, pp. 189-197.

Ford, S.E. \& H.H. Haskin, 1988. Comparison of in vitro salinity tolerance of the oyster parasite, Haplosporidium nelsoni (MSX) and hemocytes from the host, Crassostrea virginica. Comp. Biochem. Physiol., Vol. 90A, pp. 183-187.

Hewatt, W.G. \& J.D. Andrews, 1956. Temperature control experiments on the fungus disease Dermocystidium marinum of oysters. Proc. Natl. Shellfish. Assoc., Vol. 46, pp. 129-133.

Haskin, H. H. \& S. E. Ford, 1982. Haplosporidium neisoni (MSX) on Delaware Bay seed oyster beds: a host-parasite relationship along a salinity gradient. J. Invertebr. Pathol., Vol. 40, pp. 388-405.

Haskin, H.H., L.A. Stauber \& J.A. Mackin, 1966. Minchinia nelsoni n. sp. (Haplosporida, Haplosporidiidae): causative agent of the Delaware Bay oyster epizootic. Science, Vol. 153, pp. 1414-1416.

Levine, N. D., 1978. Perkinsus gen. n. and other new taxa in the protozoan phylum Apicomplexa. J. Parasitol., Vol. 64 , p. 549

Pierce, S.K., 1970. The water balance of Modiolus (Bivalvia : Mytilidae): osmotic concentrations in changing salinities. Comp. Biochem. Physiol., Vol. 38A, pp. 619-635.

Ray, S.M., 1966. Effects of various antibiotics on the fungus Dermocystidium marinum in thioglycollate cultures of oyster tissues. J. Invertebr, Pathol., Vol. 8, pp. 433-438. 